\title{
Evaluation of the Romosinuano cattle population structure in Mexico using pedigree analysis
}

\author{
Evaluación de la estructura poblacional de bovinos Romosinuano en México mediante el análisis de \\ pedigrí \\ Avaliação da estrutura populacional de bovinos Romosinuano no México usando análise de pedigree
}

Rafael Núñez-Domínguez (; Ricardo E Martínez-Rocha (; Jorge A Hidalgo-Moreno (; Rodolfo Ramírez-Valverde* (; José G García-Muñiz

Departamento de Zootecnia, Universidad Autónoma Chapingo, Chapingo, México.

Received: February 14, 2018; accepted: March 18, 2019

To cite this article:

Nuñez-Domínguez R, Martínez-Rocha RE, Hidalgo-Moreno JÁ, Ramírez-Valverde R, García-Muñiz JG. Evaluation of the Romosinuano cattle population structure in Mexico using pedigree analysis. Rev Colomb Cienc Pecu 2020; 33(1): 44-59 DOI: https://doi.org/10.17533/udea.rccp.v32n4a05

*Corresponding author: Km 38.5 Carretera México-Texcoco, Chapingo, México CP 56230. Tel.: +52-595-952-1621. E-mail: rodolforv@correo.chapingo.mx 


\begin{abstract}
Background: Romosinuano cattle breed in Mexico has endured isolation and it is necessary to characterize it in order to facilitate sustainable genetic management. Objective: To assess the evolution of the structure and genetic diversity of the Romosinuano breed in Mexico, through pedigree analysis. Methods: Pedigree data was obtained from Asociación Mexicana de Criadores de Ganado Romosinuano y Lechero Tropical (AMCROLET). The ENDOG program (4.8 version) was used to analyze two datasets, one that includes upgrading from $\mathrm{F}_{1}$ animals (UP) and the other with only straight-bred cattle (SP). For both datasets, three reference populations were defined: 1998-2003 (RP1), 2004-2009 (RP2), and 2010-2017 (RP3). The pedigree included 3,432 animals in UP and 1,518 in SP. Demographic parameters were: Generation interval (GI), equivalent number of generations (EG), pedigree completeness index (PCI), and gene flow among herds. Genetic parameters were: Inbreeding $(F)$ and average relatedness $(A R)$ coefficients, effective population size $\left(N_{e c}\right)$, effective number of founders and ancestors, and number of founder genome equivalents. Results: The GI varied from 6.10 to 6.54 for UP, and from 6.47 to 7.16 yr for SP. The EG of the UP and SP improved $>63 \%$ from RP1 to RP3. The PCI increased over time. No nucleus or isolated herds were found. For RP3, $F$ and $A R$ reached 2.08 and $5.12 \%$ in the UP, and 2.55 and $5.94 \%$ in the SP. For RP3, $N_{e c}$ was 57 in the UP and 45 in the SP. Genetic diversity losses were attributed mainly ( $>66 \%)$ to genetic drift, except for RP3 in the SP (44\%). Conclusions: A reduction of the genetic diversity has been occurring after the Romosinuano breed association was established in Mexico, and this is mainly due to random loss of genes.
\end{abstract}

Keywords: effective population size; gene flow; genetic diversity; genetic drift; generation interval; inbreeding; pedigree; population structure; probability of gene origin; Romosinuano cattle.

\title{
Resumen
}

Antecedentes: La raza bovina Romosinuano ha estado prácticamente aislada en México y requiere ser caracterizada para un manejo genético sostenible. Objetivo: Evaluar la evolución de la estructura y diversidad genética de la raza Romosinuano en México, mediante el análisis del pedigrí. Métodos: Los datos genealógicos provinieron de la Asociación Mexicana de Criadores de Ganado Romosinuano y Lechero Tropical (AMCROLET). Los análisis se realizaron con el programa ENDOG (versión 4.8) para dos bases de datos, una que incluyó animales en cruzamiento absorbente (UP) a partir de $\mathrm{F}_{1}$ y la otra con sólo animales puros (SP). Para ambas bases de datos se definieron tres poblaciones de referencia: 1998-2003 (RP1), 20042009 (RP2), y 2010-2017 (RP3). El pedigrí incluyó 3.432 animales en la UP y 1.518 en la SP. Los parámetros demográficos fueron: intervalo generacional (GI), número de generaciones equivalentes (EG), índice de completitud del pedigrí (PCI), y flujo de genes entre hatos. Los parámetros genéticos fueron: coeficientes de consanguinidad $(F)$ y de relación genética aditiva $(A R)$, tamaño efectivo de la población $\left(N_{e c}\right)$, número efectivo de fundadores y ancestros, y número equivalente de genomas fundadores. Resultados: El GI varió de 6,10 a 6,54 para la UP, y de 6,47 a 7,16 años para la SP. El EG de la UP y la SP mejoró $>63 \%$, de RP1 a RP3. El PCI aumentó a través de los años, pero más para la SP que para la UP. No se encontraron hatos núcleo o aislados. Para RP3, $F$ y $A R$ alcanzaron 2,08 y $5,12 \%$ en la UP, y 2,55 y $5,94 \%$ en la SP. Para RP3, $N_{e c}$ fue 57 en la UP y 45 en la SP. Más de $66 \%$ de las pérdidas en diversidad genética se debieron a deriva genética, excepto para RP3 en la UP (44\%). Conclusiones: una reducción de la diversidad genética ha estado ocurriendo después de que se formó la asociación de criadores de ganado Romosinuano en México, y es debida principalmente a pérdidas aleatorias de genes.

Palabras clave: consanguinidad; deriva genética; diversidad genética; estructura poblacional; flujo de genes; ganado Romosinuano; intervalo generacional; pedigrí; probabilidad de origen del gen; tamaño efectivo de población.

\section{Resumo}

Antecedentes: A raça bovina Romosinuano tem estado praticamente isolada no México e precisa ser caracterizada para um manejo genético sustentável. Objetivo: Avaliar a evolução da estrutura e diversidade genética da raça Romosinuano no México, através da análise de pedigree. Métodos: Os dados genealógicos vieram da Asociación Mexicana de Criadores de Ganado Romosinuano y Lechero Tropical (AMCROLET). As análises foram feitas com o programa ENDOG (versão 4.8) para duas bases de dados, uma que incluiu animais em cruzamento absorvente (UP) a partir da F1 e a outra base de dados somente com animais puros (SP). Para ambas bases de dados foram definidas três populações de referência: 1998-2003 (RP1), 2004-2009 (RP2) e 2010-2017 (RP3). O pedigree incluiu 3.432 animais na UP e 1.518 na SP. Os parâmetros demográficos foram: intervalo entre gerações (GI), número de gerações equivalentes (EG), índice de completude do pedigree (PCI), e fluxo de genes entre rebanhos. Os parâmetros genéticos foram: coeficiente de consanguinidade $(F)$ e da relação genética aditiva 
$(A R)$, tamanho efetivo da população $\left(N_{e c}\right)$, número efetivo de fundadores e ancestrais, e número equivalente de genomas fundadores. Resultados: O GI variou de 6,10 a 6,54 para a UP, e de 6,47 a 7,16 anos para a SP. EG da UP e a SP melhorou $>63 \%$, de RP1 a RP3. O PCI aumentou ao longo dos anos, mas mais para a SP do que para o UP. Não se encontraram rebanhos núcleo ou isolados. Para RP3, $F$ e $A R$ alcançaram 2,08 e 5,12\% na UP, e 2,55 e 5,94\% na SP. Para RP3, $N_{e c}$ foi 57 na UP e 45 na SP. Mais de $66 \%$ das perdas em diversidade genética foram ocasionadas pela deriva genética, exceto para RP3 no UP (44\%). Conclusões: Depois que a associação da raça Romosinuano foi estabelecida no México, tem ocorrido uma redução da diversidade genética, principalmente devido a perdas aleatórias de genes.

Palavras-chave: consanguinidade; deriva genética; diversidade genética, estrutura populacional; fluxo de genes; intervalo entre gerações; pedigree; probabilidade de origem do gene; Romosinuano; tamanho efetivo da população.

\section{Introduction}

Romosinuano, a Creole breed developed in Colombia, is based on cattle that arrived from the Iberian Peninsula five centuries ago. According to De Alba (2011), Romosinuano germplasm entered into México as semen. Semen from Colombia was first exported to North Carolina, USA, in the middle of the $20^{\text {th }}$ century. Then, semen was exported to Venezuela in 1982. A research herd was founded in Turrialba, Costa Rica, in 1955 using sires and heifers imported from North Caroline. Subsequently Romosinuano embryos were imported by Florida State University, from Venezuela. The Mexican herd was developed from germplasm of Turrialba, and later from genetics of Florida State University.

Several breeders in the Mexican tropics have used Romosinuano due to ease of management, longevity (Carroll et al., 2011; 2012), fertility (Riley et al., 2007), tolerance to heat, humidity (Scharf et al., 2010), and to the toxic effects of endophytes commonly present in tall fescue (Riley et al., 2016). The Asociación Mexicana de Criadores de Ganado Romosinuano y Lechero Tropical (AMCROLET) was established in 1998 (DeAlba, 2011), and it is responsible for the herdbook and the performance records. Recently, the first Romosinuano genetic evaluation in Mexico was carried out (AMCROLET, 2016), which would allow breeders to identify superior breeding stock for genetic improvement. However, the selection of breeding stock may result in a smaller population size and in higher inbreeding (Bernardes et al., 2016). This is even more important considering that the Mexican herd of Romosinuano is relatively isolated due to sanitary restrictions that would not allow import genetic material directly from Colombia (SAGARPA, 2017).

The main goal of conservation programs is to control the effects of genetic drift in order to maintain the genetic variability of the population and to keep a low rate of inbreeding (Jamieson and Allendorf et al., 2012; Hammerly et al., 2013; Toro et al., 2014). Genetic variability works simmilar to an 'insurance' for the population to face potential environmental and marketing changes; at the same time, it reduces the unfavorable effects on performance due to inbreeding (Burrow et al., 1993; Santana et al., 2012). The studies on genetic variability of populations have been conducted using pedigree analysis or genetic markers. Pedigree information provides a useful tool for conservation programs to maintain genetic variability and minimize inbreeding (Pinheiro et al., 2013; Santana et al., 2016; Sheikhlou and Abbasi et al., 2016).

Considering the potential of Romosinuano cattle to improve beef production under tropical conditions, the availability of predicted breeding values, and the fact that it is a breed with a small population size and relatively isolated, it is imperative to characterize the structure of this population and evaluate changes in its genetic variability. Therefore, the objective of this study was to assess the evolution of the structure and genetic diversity of Romosinuano breed in Mexico through pedigree analysis. 


\section{Materials and methods}

\section{Description of the data}

Pedigree data (identification of animal, sire and dam, sex, birth date and herd) was obtained from AMCROLET. The database included 4,809 animals born between 1953 and 2017, belonging to 39 herds located mainly in the Southeast region of Mexico.

Given that the Romosinuano population has been developing from upgrading, pedigree analyses were performed for two datasets: one that includes upgrading from $\mathrm{F}_{1}$ animals (UP; $\mathrm{n}=$ 3,432 ) and the other with only straightbred cattle (SP; $\mathrm{n}=1,518$ ); thus, SP is included in UP. For both datasets, three reference populations were defined: 1998-2003 (RP1), 2004-2009 (RP2), and 2010-2017 (RP3) to describe the time-trend of pedigree parameters for approximately three generation intervals after AMCROLET was created.

\section{Pedigree analyses}

The analyses of genealogical information were carried out using ENDOG version 4.8 (Gutiérrez and Goyache, 2005).

\section{Demographic parameters}

Generation interval (GI). The GI (average age of the parents when their replacements were born) was obtained for the four gametic paths (sire-son, sire-daughter, dam-son, damdaughter).

Pedigree completeness level. To evaluate the level of integrity of the pedigree, the number of complete (CG), maximum (MG) and equivalent (EG) generations were calculated. The CG implies that the $2^{n}$ ancestors of an animal are known, where $n$ is the number of fully traced generations, whereas MG counts the number of generations that separate the animal from the oldest ancestor (Gutiérrez y Goyache et al., 2005). For a given animal, EG was calculated as the sum of $(1 / 2)^{n}$ coefficients of all known ancestors, where $n$ is the number of generations separating the individual to each known ancestor (Maignel et al., 1996). The percentage of known ancestors during the last three generations was calculated, a period that encompasses the time from AMCROLET formation. Finally, the pedigree completeness index (PCI; MacCluer $e t$ al., 1983) was generated for each generation.

Gene flow among herds. The role of each herd was evaluated according to the contribution of the sires to the population (Vassallo et al., 1986). Herds were grouped as: a) nucleus, if breeders only use their own sires, which may also be sent to other herds; b) multiplier, when breeders use sires from other herds and provide them to other herds; c) commercial, if breeders use sires from other herds, but do not deliver sires; and d) isolated, when breeders only use own sires and do not provide them to other herds.

\section{Genetic parameters}

Inbreeding $(F)$ and average relatedness coefficients (AR). The $F$ was calculated using the algorithm of Meuwissen and Luo et al. (1992), assuming unrelated and noninbred founders. For each animal, $A R$ was defined as the probability that an allele randomly chosen in the population belongs to a particular animal (Gutiérrez and Goyache et al., 2005). The $A R$ for a particular animal is equivalent to the average of the coefficients in the row of the numerator relationship matrix.

Effective population size $\left(N_{e}\right)$. The $N_{e}$ was estimated using two methods. The first was based on the individual increase in inbreeding $\left(\Delta \mathrm{F}_{i}\right)$ and was computed as follows (Gutiérrez et al., 2009):

$$
\Delta F_{i}=1-\sqrt[t-1]{1-F_{i}}
$$


where, $t$ is the number of equivalent generations. The $N_{e}$ was calculated from the average of the inbreeding rate of the $n$ animals included, as .

$$
\overline{N_{e}}=\frac{1}{2 \overline{\Delta F}}
$$

The second method was based on increases in coancestry $\left(\Delta c_{j k}\right)$ between any pair of individuals $j$ and $k$ (Cervantes et al., 2011), as:

$$
\Delta c_{j k}=1-\frac{\frac{g_{j}+g_{k}}{2}}{1-c_{j k}}
$$

where, $c_{j k}$ is the inbreeding of a progeny from $j$ and $k$, and $g_{j}$ and $g_{k}$ are the discrete equivalent generation for the parents. Then, $N_{e}$ was estimated by averaging the rate of coancestry $\left(N_{e c}\right)$ for all pairs of the individuals as.

$$
\overline{N_{e c}}=\frac{1}{2 \overline{\Delta c}} \text {. }
$$

Probability of gene origin. To assess the amount and kind of genetic diversity losses in the populations, the number of founders $(f)$, effective number of founders $\left(f_{e}\right)$, effective number of ancestors $\left(f_{a}\right)$, and founder genome equivalents $\left(f_{g}\right)$ were obtained. The $f_{e}$ counts founders with unknown genetic relationships with other animals in the pedigree, except to its descendant (Lacy, 1989). Preservation of genetic diversity of founders toward the studied population may be evaluated by its contributions, that must add up to one (Boichard et al., 1997).

The $f_{e}$ is the number of equally contributing founders that would be expected to produce the same amount of genetic diversity as observed in the population under study (Lacy, 1989), and was calculated as:

$$
f_{e}=\frac{1}{\sum_{k=1}^{f}\left(p_{k}^{2}\right)}
$$

where, $p_{k}$ is the probability of gene origin of founder $k$ to the reference population. The $f_{a}$ is the minimum number of ancestors (founders or not) needed to explain the full genetic diversity of the population (Boichard et al., 1997), and it was obtained as:

$$
f_{a}=\frac{1}{\sum_{i=1}^{a}\left(p_{i}^{2}\right)}
$$

where, $p_{i}$ is the marginal contribution of the $i^{\text {th }}$ ancestor (genetic contribution not yet explained by other ancestor chosen before), and $a$ is the number of influential ancestors (i.e. ancestors with non-zero marginal contributions). Additionally, based on the marginal contributions, the number of ancestors explaining $50 \%$ of the genes in the population and the contribution of the main ancestor were obtained.

The $f_{g}$ was calculated as the inverse of twice the average coancestry of individuals in the predefined reference population. This parameter accounts for all causes of loss of genetic diversity in the population (Caballero and Toro et al., 2000).

The effective number of non-founders $\left(f_{n}\right)$ accounts only for the genetic drift effects in non-founder generations (Caballero and Toro et al., 2000):

$$
\frac{1}{f_{g}}=\frac{1}{f_{e}}+\frac{1}{f_{n}}
$$

Thus, the $f_{g}$ has two components, $f_{e}$ that accounts for the contributions of founders to the actual population, and $f_{n}$ which accounts for the contribution of non-founders, and is accumulated over generations. Based on these parameters, the genetic diversity (GD) in the reference population relative to the base population was obtained as (Lacy, 1989, 1995):

Therefore, 1 - GD represents the loss of genetic diversity in the population since the 
founder generation. The loss of genetic diversity because of unequal contributions of founders was estimated as $1-\mathrm{GD}^{*}$, where (Caballero and Toro et al., 2000):

Finally, the difference between GD and GD* accounts for the loss of genetic diversity due to genetic drift accumulated over the non-founder generations (Caballero and Toro, 2000), and it can be expressed as the inverse of twice the number of non-founders (Lacy, 1995).

\section{Results}

\section{Demographic parameters}

For the UP, average GI was similar from RP1 to RP3 (6.51 to $6.54 \mathrm{yr}$ ); however, for the SP these values tended to decrease from 7.16 in RP1 to $6.57 \mathrm{yr}$ in RP3 (Table 1). Among parentoffspring pathways, the GI for path sire-son were larger and tended to decrease from RP1 to RP3 in both the UP and the SP, and were half to one year longer for the SP than the UP.

Table 1. Generation intervals (yr) for the upgraded and straightbred Romosinuano and their respective reference populations (RP1, RP2, and RP3).

\begin{tabular}{|c|c|c|c|c|c|c|}
\hline \multirow{2}{*}{ Breeding paths } & \multicolumn{3}{|c|}{ Upgraded (UP) } & \multicolumn{3}{|c|}{ Straightbred (SP) } \\
\hline & RP1 & RP2 & RP3 & RP1 & RP2 & RP3 \\
\hline Sire-son & 8.41 & 7.81 & 6.97 & 8.98 & 8.20 & 7.96 \\
\hline Sire-daughter & 6.73 & 5.83 & 6.12 & 7.53 & 5.93 & 6.38 \\
\hline Dam-son & 5.84 & 7.02 & 6.79 & 5.87 & 6.73 & 6.35 \\
\hline Dam-daughter & 5.68 & 6.83 & 6.79 & 5.59 & 6.55 & 6.44 \\
\hline Parent-offspring & 6.41 & 6.42 & 6.54 & 7.16 & 6.47 & 6.57 \\
\hline
\end{tabular}

Generation intervals $=$ average age of the parents when their replacements are born; RP1 = 1998-2003; RP2 = 2004-2009; RP3 = 2010-2017.

Table 2. Number of maximum (MG), complete (CG) and equivalent (EG) generations traced for the upgraded and straightbred Romosinuano and their respective reference populations (RP1, RP2, and RP3).

\begin{tabular}{llccccc}
\hline \multirow{2}{*}{ Generations } & \multicolumn{3}{c}{ Upgraded (UP) } & \multicolumn{3}{c}{ Straightbred (SP) } \\
\cline { 2 - 7 } & RP1 & RP2 & RP3 & RP1 & RP2 & RP3 \\
\hline MG & 5.34 & 7.24 & 9.02 & 5.15 & 7.07 & 8.80 \\
CG & 0.82 & 1.07 & 1.17 & 0.47 & 0.96 & 1.56 \\
EG & 2.10 & 2.89 & 3.43 & 1.75 & 2.54 & 3.34 \\
\hline
\end{tabular}

RP1 = 1998-2003; RP2 = 2004-2009; RP3 = 2010-2017.

The level of completeness of the UP and the SP pedigrees improved from RP1 to RP3 more than 69, 43 and 63\% for $\mathrm{MG}, \mathrm{CG}$ and $\mathrm{EG}$, respectively, after herd-book recording started (Table 2).
The EG reached 3.43 and 3.34 yr for the UP and the SP in RP3. The percentage of known ancestors improved during the recent $20 \mathrm{yr}$ and for the UP averaged 76,73 and $66 \%$ for the generations of parents, grandparents and greatgrandparents, respectively, and those values for the SP were 93, 85 and 65\% (Table 3); thus, the improvement was higher for the SP. 
Table 3. Percentage of known ancestors by generation for the upgraded and straightbred Romosinuano and their respective reference populations (RP1, RP2, and RP3).

\begin{tabular}{lcccccc}
\hline \multirow{2}{*}{ Generation } & \multicolumn{3}{c}{ Upgraded (UP) } & \multicolumn{3}{c}{ Straightbred (SP) } \\
\cline { 2 - 7 } & RP1 & RP2 & RP3 & RP1 & RP2 & RP3 \\
\hline Parents & 78.00 & 80.50 & 75.50 & 70.50 & 85.50 & 93.00 \\
Grandparents & 57.75 & 71.50 & 73.00 & 51.25 & 70.00 & 85.00 \\
Great-grandparents & 33.88 & 56.75 & 65.50 & 26.50 & 46.88 & 65.25 \\
\hline
\end{tabular}

RP1 = 1998-2003; RP2 = 2004-2009; RP3 = 2010-2017.

Considering various generations, there was a steady improvement of the PCI during the recent $20 \mathrm{yr}$ (Figure 1). Including three generations back, the PCI of RP3 were similar, 65.3 and $65.2 \%$ for the UP and the SP, but it increased to 75.4 and $93.1 \%$, respectively, when only one generation was considered.



Figure 1. Pedigree completeness index for the upgraded (UP) and straightbred (SP) Romosinuano and their respective reference populations (RP1, 1998-2003; RP2, 2004-2009; and RP3, 2010-2017) for generations 1 to 6 .

Mostly multiplier herds were found in this Romosinuano population (67 and $77 \%$ in the UP and the SP, respectively). Commercial herds in the UP were about twice as many as those in the SP, while no nucleus was found (Table 4).
Table 4. Classification of herds according to the origin and use of sires for the upgraded (UP) and straightbred (SP) Romosinuano populations.

\begin{tabular}{lccccccc}
\hline \multirow{2}{*}{ Item } & \multirow{2}{*}{ UFS } & \multirow{2}{*}{ UOS } & \multirow{2}{*}{ SS } & \multicolumn{2}{c}{ UP } & \multicolumn{2}{c}{ SP } \\
\cline { 5 - 8 } & & & & NoH & PFS & NoH & PFS \\
\hline Nucleus & No & Yes & Yes & 0 & 0 & 0 & 0 \\
Multiplier & Yes & Yes & Yes & 15 & 91 & 12 & 88 \\
Multiplier & Yes & No & Yes & 11 & 100 & 12 & 100 \\
Commercial & Yes & Yes & No & 0 & 0 & 0 & 0 \\
Commercial & Yes & No & No & 13 & 100 & 7 & 100 \\
Isolated & No & Yes & No & 0 & 0 & 0 & 0 \\
\hline
\end{tabular}

UFS = use foreign sires; UOS = use own sires; $\mathrm{SS}=$ sell sires; $\mathrm{NoH}=$ number of herds; PFS $=$ percent of foreign sires.

As previously indicated, development of Mexican Romosinuano population was based mainly on germplasm importation from a herd in Turrialba, Costa Rica (herd 75), which is depicted in Figure 2. Regarding the UP, some herds (e.g. herd 12) included a large number of dams in upgrading to Romosinuano. In the $\mathrm{SP}$, the genetic representation of herd 75 is declining, whereas that of Mexican herds are increasing (e.g. herd 40; 9.7 to $23.5 \%$ from RP1 to RP3, respectively). 



Figure 2. Main founder herds genetically represented (\%) in RP1 (1998-2003), RP2 (2004-2009), and RP3 (2010-2017) in upgraded (UP) and straightbred (SP) Romosinuano populations.

\section{Genetic parameters}

Generally, all inbreeding statistics increased from RP1 to RP3 (Table 5). Considering RP3, all inbreeding statistics were higher in the SP than the UP, except for the percentage of average inbreeding in inbred animals.

Table 5. Inbreeding statistics (\%) for upgraded and straightbred Romosinuano and their respective reference population (RP1, RP2, and RP3).

\begin{tabular}{|c|c|c|c|c|c|c|}
\hline \multirow{2}{*}{ Item } & \multicolumn{3}{|c|}{ Upgraded (UP) } & \multicolumn{3}{|c|}{ Straightbred (SP) } \\
\hline & RP1 & RP2 & RP3 & RP1 & RP2 & RP3 \\
\hline IA & 34.52 & 44.57 & 42.07 & 23.08 & 49.49 & 65.83 \\
\hline $\mathrm{AR}$ & 4.26 & 5.07 & 5.12 & 4.38 & 5.56 & 5.94 \\
\hline IP & 0.97 & 2.17 & 2.08 & 0.65 & 1.99 & 2.55 \\
\hline IF & 2.82 & 4.88 & 4.94 & 2.80 & 4.01 & 3.87 \\
\hline
\end{tabular}

$\mathrm{RP} 1=1998-2003 ; \mathrm{RP} 2=2004-2009 ; \mathrm{RP} 3=2010-2017 ; \mathrm{IA}=$ inbred animals; $\mathrm{AR}=$ average relatedness; IP = average inbreeding in the population; IF $=$ average inbreeding in inbred animals.

Table 6. Average inbreeding coefficients $(F)$, inbred animals and relatedness coefficients $(A R)$ for upgraded and straightbred Romosinuano populations, by complete generations.

\begin{tabular}{|c|c|c|c|c|c|}
\hline Generation & $\mathbf{N}$ & $F(\%)$ & Inbred animals $(\%)$ & $F$ in inbred animals $(\%)$ & $A R(\%)$ \\
\hline \multicolumn{6}{|c|}{ Upgraded population (UP) } \\
\hline 0 & 1,610 & 0.00 & 0.00 & 0.00 & 3.21 \\
\hline 1 & 702 & 1.61 & 51.14 & 3.14 & 4.86 \\
\hline 2 & 739 & 3.59 & 78.21 & 4.59 & 6.18 \\
\hline 3 & 341 & 5.52 & 100.00 & 5.52 & 7.23 \\
\hline 4 & 40 & 6.65 & 100.00 & 6.65 & 8.57 \\
\hline \multicolumn{6}{|c|}{ Straightbred population (SP) } \\
\hline 0 & 474 & 0.00 & 0.00 & 0.00 & 3.28 \\
\hline 1 & 538 & 1.91 & 58.18 & 3.29 & 5.68 \\
\hline 2 & 436 & 3.46 & 80.73 & 4.28 & 6.79 \\
\hline 3 & 70 & 3.68 & 100.00 & 3.68 & 7.20 \\
\hline
\end{tabular}


When inbreeding statistics were obtained for complete generations in the UP and the SP (Table 6) the average $F$ reached 6.7 and $3.7 \%$, respectively, and all animals were inbred in the most recent generations ( 3 and 4 for the UP and 3 for the SP). The $A R$ has been increasing every complete generation from 3.2 and $3.3 \%$ to 8.6 and $7.2 \%$ for the UP and the SP, respectively.
Even when both $N_{e}$ and $N_{e c}$ were larger for the UP than the SP, for $N_{e}$ there was a reduction of these sizes in RP2 and a subsequent increase to reach sizes of 79 and 48 in RP3 (Table 7).

Estimates of $N_{e c}$ were smaller than $N_{e}$ and increased over the recent $20 \mathrm{yr}$ for the UP and the SP, reaching in RP3 57 and 45, respectively

Table 7. Realized effective population size $\left(N_{e}\right)$ and effective population size from an increase in coancestry $\left(N_{e c}\right)$ for the upgraded and straightbred Romosinuano and their respective reference populations (RP1, RP2, and RP3).

\begin{tabular}{lccc}
\hline Item & RP1 & RP2 & RP3 \\
\hline & & Upgraded & 78.51 \\
\hline$N_{e}$ & 61.99 & 49.08 & 56.53 \\
$N_{e c}$ & 39.49 & 44.92 & \\
\hline & & Straightbred & 47.68 \\
\hline$N_{e}$ & 46.19 & 34.93 & 44.81 \\
$N_{e c}$ & 35.32 & 38.45 & \\
\hline
\end{tabular}

RP1 = 1998-2003; RP2 = 2004-2009; RP3 = 2010-2017.

The parameters describing the probabilities of gene origin for the UP and the SP and their respective reference populations (RP1, RP2, and RP3) are shown in Table 8. The $f$ in the UP were larger than in the SP and increased from RP1 (273) to RP3 (827). Although $f_{e}$ remained approximately constant across reference populations the ratio $f / f$ for the UP decreased from RP1 $(22.0 \%)$ to RP3 $(7.4 \%)$ whereas those ratios for the SP were larger and varied from
20.3 to $32.2 \%$. During the last 20 years, $f_{a}$ in the SP decreased $16.7 \%$ from RP1 to RP3 and $f_{g}$ had a reduction of 17.6 and $30.1 \%$ for the UP and the SP, respectively. The $f_{a}$ represented about $50 \%$ of the $f_{e}$. The $f_{g}$ represented 27 and $33 \%$ of $f_{e}$ for the UP and the SP, respectively. From RP1 to RP3 there was a reduction of the proportion of founder genomes that have been retained in the reference populations $\left(f_{g} / f\right)$, from 7.3 to $2.0 \%$ in the UP and from 10.6 to $7.4 \%$ in the SP.

Table 8. Probability of gene origin parameters for the upgraded and straightbred Romosinuano and their respective reference populations (RP1, RP2, and RP3).

\begin{tabular}{|c|c|c|c|c|c|c|}
\hline \multirow{2}{*}{ Item } & \multicolumn{3}{|c|}{ Upgraded (UP) } & \multicolumn{3}{|c|}{ Straightbred (SP) } \\
\hline & RP1 & RP2 & RP3 & RP1 & RP2 & RP3 \\
\hline$F$ & 273 & 527 & 827 & 183 & 251 & 184 \\
\hline$f_{e}$ & 60 & 56 & 61 & 59 & 51 & 50 \\
\hline$f_{a}$ & 31 & 29 & 33 & 30 & 24 & 25 \\
\hline$f_{g}$ & 20.0 & 16.7 & 16.5 & 19.3 & 15.4 & 13.5 \\
\hline$C_{\max }, \%$ & 11.0 & 9.9 & 8.6 & 9.8 & 10.3 & 9.9 \\
\hline$N_{50}$ & 12 & 10 & 11 & 11 & 9 & 9 \\
\hline
\end{tabular}

$\mathrm{RP} 1=1998-2003 ; \mathrm{RP} 2=2004-2009 ; \mathrm{RP} 3=2010-2017 ; f=$ number of founders; $f_{e}=$ effective number of founders; $f_{a}=$ effective number of ancestors; $f_{g}=$ equivalent number of founder genomes; $C_{\max }=$ contribution of the main ancestor; $N_{50}=$ number of ancestors explaining $50 \%$ of the gene pool. 
Total losses of genetic variability from RP1 to RP3 increased from 2.5 to $3.0 \%$ in the UP and from 2.6 to $3.7 \%$ in the SP (Figure 3).



$\mathrm{GD}^{*-\mathrm{GD}}$
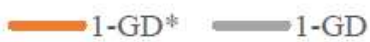

More than $66 \%$ of the losses on genetic diversity were accounted for genetic drift, except for RP3 in the SP (44\%).

Figure 3. Losses (\%) of genetic diversity due to genetic drift (GD*-GD), unequal founder contribution (1-GD*), and both reasons (1-GD) since the founder generation in upgraded (UP) and straightbred (SP) Romosinuano reference populations (RP1, 1998-2003; RP2, 2004-2009; and RP3, 2010-2017).

The main ancestor contributed 8.6 to 11.0 , and 9.8 to $10.3 \%$ of the genes in the UP and the SP, respectively. The numbers of ancestors that explained half of the genetic variability of the populations ranged from 10 to 12 in the UP, and 9 to 11 in the SP, with a decreasing trend from RP1 to RP3.

\section{Discussion}

The average GI observed in the present study for the different reference populations (6.41 to $6.54 \mathrm{yr}$ for UP and 6.47 to $7.16 \mathrm{yr}$ for SP; Table 1) were larger than those of Colombian creole breeds such as Costeño con Cuernos (CCC, 5.4 yr), Blanco Orejinegro (BON, 4.7 yr) and Romosinuano (ROM, 5.7 yr), but similar to Sanmartinero (SM, 6.8 yr) (Martínez et al., 2008), and to Brazilian Lageana Crioula cattle breed (6.41 yr; Pezzini et al., 2018). Gutiérrez et al. (2003) estimated an interval of GI in eight autochthonous Spanish cattle breeds (Alistana, Asturiana de la Montaña, Asturiana de los Valles, Avileña-Negra Ibérica, Bruna dels Pirineus, Morucha, Pirenaica and Sayaguesa) of 3.7 to $6.1 \mathrm{yr}$. However, compared to the present study, larger GI were reported in Kumamoto (9.4 yr) and Kouchi (10.4 yr)
Japanese Brown cattle breeds (Honda et al., 2006). Differences of GI among breeds may be the result of variations in calving age, fluctuating environmental conditions throught the years in the tropic (Rosendo et al., 2018), number of years that sires and dams are used, and breeding objectives; for example, large GI are convenient in conservation breeding programs.

Regarding the integrity of the pedigree, the EG of the present study increased during the recent $20 \mathrm{yr}$ and reached in RP3, 3.43 for UP and 3.34 for SP (Table 2). Those estimates were smaller than those for Romosinuano (4.8), SM (3.8) and CCC (3.7) Colombian creole breeds (Martínez et al., 2008) but higher than the interval 0.81 to 2.97 in eight Spanish autochthonous breeds (Gutiérrez et al., 2003), the EG in BON (3.1; Martínez et al., 2008), and the estimate in Lageana Crioula cattle breed (0.77, Pezzini et al., 2018). The PCI is an important measure of the quality of inbreeding estimates from the pedigree since PCI represents a harmonic mean of parental genetic contributions and equals zero if any parent is unknown regardless of how deep and complete is the pedigree for the other parent. Similarly, inbreeding can be estimated only if information for both parents is known 
(Battagin et al., 2010; Onogi et al., 2017). Estimates of PCI in RP3 from the present study (65.3 for UP and $65.2 \%$ for SP, and considering three generations back, and 75.4 and $93.1 \%$ considering one generation back; Figure 1) were lower than the PCI (90 and 69\% in 2009 considering 2 and 5 generations, respectively) observed by Battagin et al. (2010) in Burlina native Italian cattle, and those reported by Santana et al. (2014) for Brazilian Gir cattle (99.8, 96.3 and $92.8 \%$ for generations 1, 2 and 3 , respectively). The observed differences of EG and PCI among studies could be the result of variations in the number of generations traced and the quality of pedigree recording.

The three different ways to evaluate the degree of pedigree completeness (number of $\mathrm{MG}, \mathrm{CG}$ and EG; percentage of known ancestors up to three generations; and PCI) indicated that for the UP and the SP the integrity of the pedigree was improved during the latest $20 \mathrm{yr}$. It is clear that an important progress has occurred after AMCROLET was established; however, these alternative measures suggest that greater efforts are needed in the recording of genealogical data to improve the accuracy of inbreeding parameters in this population (Boichard et al., 1997).

Given that Romosinuano breed was developed in Colombia and later introduced into Mexico, no nucleus herds were found. The high proportion of multiplier herds found in the present study indicates that the population is growing. Similar results were reported by Silva et al. (2016). Since the demand for Romosinuano germplasm in Mexico is increasing, commercial herds in the UP were about twice as many as those in the SP. Mexican herds (like herd 40, Figure 3) are having an increasing genetic representation in the population. Thus, it is beneficial if breeders share germplasm from various herds to avoid short-term significant increases in inbreeding, with the consequent reduction in animal performance (Burrow, 1993; Santana et al., 2012). Germplasm used in the UP matings mainly comes from the SP; thus, it is important to compare results of the SP and RP3 with other studies. The percentage of inbred animals in SP $(65.8 \%)$ was higher than the range 5.8 to $30.8 \%$ in Colombian creole breeds (Martínez et al., 2008), and the interval 2 to $32 \%$ in Spanish autochthonous breeds (Gutiérrez et al., 2003), but lower than in Alentejana Portuguese (nearly $80 \%$; Carolino and Gama, 2007), and in Burlina Italian cattle (>80\%; Battagin et al., 2010). Possible causes of these differences among studies could be the pedigree completeness, monitoring of matings to avoid inbreeding, and gene flow among herds. Even though averages of $F$ for the Romosinuano breed in Mexico have been increasing during the last $20 \mathrm{yr}$, they are still low (2.5 and 3.9\% for all and inbred animals, respectively; Table $5)$. Lower values $(<1.41 \%$ for the reference population, and $<3.21 \%$ for inbred animals) were estimated for various breeds by Martínez et al. (2008), except for Romosinuano that had 3.1 and $4.0 \%$, respectively. These differences may be due mainly to variations in effective population sizes, integrity level of the pedigree, and efficacy to prevent inbreeding. The $A R$ was high $(5.9 \%)$ as compared to the interval 2.0 to $3.9 \%$ reported by Martínez et al. (2008) in four Colombian breeds, and the range 0.10 to $1.70 \%$ by Gutiérrez et al. (2003) in eight Spanish breeds. The size of $A R$ is important to predict the $F$ of following generations since, under random mating, $F$ of the progeny will be half of the $A R$ between parents. For RP3, in the SP the expected $F$ in the following generation would be still low at about 3\%. However, these estimates may be biased downward because of incomplete pedigree data since pedigree recording in the Romosinuano Herd-Book was formally carried out after AMCROLET was created (1998).

The average $N_{e c}$ and $N_{e}$ reached 45 and 48 in RP3 SP, respectively (Table 7). The $N_{e}$ estimates from the present study are within the range (21 to 123 ) published by Gutiérrez et al. (2003). Larger values of $N_{e}$ were reported in Romosinuano (66), BON (260), and CCC (143) Colombian breeds, except for SM (27) (Martínez 
et al., 2008), in Tabapuã (411; Bernardes et al., 2016), and in Brazilian Gir cattle (94; Santana et al., 2014). Estimates of $N_{e c}$ were smaller than $N_{e}$ and increased over the last $20 \mathrm{yr}$. Smaller values of $N_{e c}$ than $N_{e}$ were also reported by Santana et al. (2012) for Marchigiana (98 vs 140) and Bonsmara (55 vs 325) cattle breeds. However, Santana et al. (2014) found higher $N_{e c}$ than $N_{e}$ in Brazilian Gir (166 vs 94). As indicated by Cervantes et al. (2011), the differences between $N_{e}$ and $N_{e c}$ are mainly due to population substructures (caused by mating policies, breeding goals or geographical distances) that affect the increase in $F$, while the increase in coancestry practically does not change. For RP3 in the SP, the size of $N_{e c}$ (45) was lower than the limit $(>50)$ recommended for conservation of genetic resources to have rates of inbreeding per generation smaller than 1.0\% (FAO, 1998).

In the present study, there was an uncommon relationship between $N_{e}$ and $F$, since there was a trend on both parameters to increase over time (Tables 5 and 7). There is a direct relationship between $N_{e}$ and . Additionally, we expect that as $N_{e}$ increases, $F$ decreases. However, sometimes this does not happen, since the depends not only on the $F$, but also on the number of equivalent generations (). Other authors have reported this situation; for example, Rosendo et al. (2018) published $N_{e}$ of 68.1 for the total and 64.6 for the selection nucleus Tropical Milking Criollo cattle, but corresponding $F$ were 1.07 and 2.14.

Boichard et al. (1997) indicated that $F$ trend, although commolnly used to quantify the rate of genetic drift, has some limitations; particularly when the pedigree completeness is low. The analysis of probabilities of gene origin is suggested as a complementary approach. In the present study, the $f_{e} / f$ ratio indicated that part of the initial genetic variability was lost due to unbalanced gene contributions of founders to the reference populations (Boichard et al., 1997). Additionaly, the $f_{a}$ represented about $50 \%$ of the $f_{e}$, which results from bottlenecks during the development of the population. Estimates of $f_{g}$ for RP3 in the UP and the SP (Table 8) indicate that the amount of genetic diversity can be generated by 17 and 14 unrelated founders, respectively (Lacy, 1989; Ballou and Lacy, 1995).

Both, genetic drift and unbalanced founder contributions of genes to the reference populations were responsible for the reduction of genetic diversity, and the former accounted for $>66 \%$ of the total losses, except for the SP most recent reference population (44\%). Honda et al. (2006) also reported that the decay in genetic diversity in Kumamoto and Kouchi subbreeds of Japanese Brown cattle was due mainly to accumulated genetic drift $(>78 \%$, except for Kumamoto, 16\%, in 2000 reference population; estimated by the authors of the present study).

The numbers of ancestors that explained $50 \%$ of the genetic variability of Romosinuano in the present study (9 to 12) were similar to Lageana Crioula breed (10; Pezzini et al., 2018), Romosinuano (8) and CCC (12), but smaller than SM (22) and BON (22) Colombian breeds (Martínez et al., 2008), Marchigiana (13) and Bonsmara (41) (Santana et al., 2012), and Gir (38; Santana et al., 2014).

The estimates of demographic and genetic parameters suggest that the Romosinuano population in Mexico is on the borderline of risk status. One of the purposes of conservation is to maintain, as much as possible, the genetic diversity present in the founder population. Among the alternatives to maintain high levels of genetic diversity in the population, the most efficient has been to minimize the average pairwise coancestries every generation and by definition to maximize $f_{g}$ (Ballou and Lacy, 1995; Lacy 1995; Caballero and Toro, 2000). Therefore, it is important that Romosinuano breeders contribute to reduce losses of genetic variability through matings designed to minimize average pairwise coancestries and a more balanced use of sires. 
In conclusion, reduction of the genetic diversity has been occurring since the Romosinuano breed association was established in Mexico, mainly due to random losses of genes. Even though no nucleus herds were found in this study, there was a tendency to concentrate the use of germplasm from a reduced number of herds; therefore, it is important to diversify the sources of genetic material for future matings. Monitoring genetic parameters and defining matings aimed to minimize pairwise coancestries are suggested to increase the effective population size and thus, to reduce the inbreeding rate per generation. Efforts are needed to improve the level of completeness of the pedigree and the accuracy of estimates of demographic and genetic parameters.

\section{Declarations}

\section{Acknowledgements}

The authors want to thank the people at Asociación Mexicana de Criadores de Ganado Romosinuano y Lechero Tropical (AMCROLET) for allowing us to use their database.

\section{Conflicts of interest}

The authors declare they have no conflicts of interest with regard to the work presented in this report.

\section{Author contributions}

This study was designed and directed by Rafael Núñez Domínguez, Ph.D. and Rodolfo Ramírez Valverde, Ph.D. Part of the study was presented as a Professional Thesis by Ricardo E. Martínez Rocha, M.C. All co-authors were closely involved in the collection, analysis and interpretation of data as well as in the writing and decision to submit the work for publication.

\section{References}

AMCROLET. Resumen de la evaluación genética para sementales Romosinuano 2016. Chapingo, México. Asociación Mexicana de Criadores de Ganado Romosinuano y Lechero Tropical, AC; 2017.

Ballou JD, Lacy RC. Identifying genetically important individuals for management of genetic diversity in pedigreed populations. In: Ballou JD, Gilpin M, Foose TJ, editors. Population Management for Survival \& Recovery. Analytical Methods and Strategies in Small Population Conservation. New York: Columbia University Press; 1995. p.76-111.

Battagin M, Penasa M, Pretto D, Cassandro M. Pedigree analysis of Burlina cattle population. Acta Agrar Kaposv 2010; 14:161-5.

Bernardes PA, Grossi DA, Savegnago RP, Buzanskas ME, Ramos SB, Romanzini EP, Guidolin DGF, Bezerra LAF, Lôbo RB, Munari DP. Population structure of Tabapuã beef cattle using pedigree analysis. Livest Sci 2016; 187:96-101. https://doi.org/10.1016/j. livsci.2016.03.002

Boichard D, Maignel L, Verrier E. The value of using probabilities of gene origin to measure genetic variability in a population. Genet Sel Evol 1997; 29:5-23. https://doi.org/10.1186/12979686-29-1-5

Burrow HM. The effects of inbreeding in beef cattle. Anim Breed Abstr 1993; 61:737-51.

Caballero A, Toro M. Interrelations between effective population size and other pedigree tools for the management of conserved populations. Genet Res 2000; 75:331-43. https://doi.org/10.1017/S0016672399004449

Carolino N, Gama LT. Indicators of genetic erosion in an endangered population: The Alentejana cattle breed in Portugal. J Anim Sci 2007; 86:47-56. https://doi.org/10.2527/jas.2007-0148 
Carroll JA, Burdick NC, Reutera RR, Chase CCJr, Spiers DE, Arthington JD, Coleman SW. Differential acute phase immune responses by Angus and Romosinuano steers following an endotoxin challenge. Domest Anim Endocrin 2011; 41:163-73. https://doi.org/10.1016/j. domaniend.2011.06.002

Carroll JA, Burdick NC, Chase CCJr, Coleman $\mathrm{SW}$, Spiers DE. Influence of environmental temperature on the physiological, endocrine, and immune responses in livestock exposed to a provocative immune challenge. Domest Anim Endocrin 2012; 43:146-53. https://doi. org/10.1016/j.domaniend.2011.12.008

Cervantes I, Goyache F, Molina A, Valera M, Gutiérrez JP. Estimation of effective population size from the rate of coancestry in pedigreed populations. J Anim Breed Genet 2011; 128:56-63. https://doi.org/10.1111/j.1439$\underline{0388.2010 .00881 . \mathrm{x}}$

De Alba J. El Libro de los Bovinos Criollos de América. Biblioteca Básica de Agricultura. Montecillo (Estado de México): Ed. Colegio de Postgraduados. 2011.

FAO (Food and Agriculture Organization for the United Nations). Secondary guidelines for development of national farm animal genetic resources management plans: Management of small populations at risk. Rome, Italy; 1998.

Gutiérrez JP, Altarriba J, Díaz C, Quintanilla R, Cañón J, Piedrafita J. Pedigree analysis of eight Spanish beef cattle breeds. Genet Sel Evol 2003; 35:43-63. https://doi.org/10.1186/1297-9686-35-1-43

Gutiérrez JP, Goyache F. A note on Endog: a computer program for analysing pedigree information. J Anim Breed Genet 2005; 122:172-76. https://doi.org/10.1111/j.14390388.2005.00512.X
Gutiérrez JP, Cervantes I, Goyache F. Improving the estimation of realized effective population sizes in farm animals. J Anim Breed Genet 2009; 126:327-32. https://doi.org/10.1111/j.1439$\underline{0388.2009 .00810 . \mathrm{x}}$

Hammerly SC, Morrow ME, Johnson JA. A comparison of pedigree- and DNA-based measures for identifying inbreeding depression in the critically endangered Attwater's Prairiechicken. Mol Ecol 2013; 22:5313-28. https:// doi.org/10.1111/mec.12482

Honda T, Fujii T, Nomura T, Mukai F. Evaluation of genetic diversity in Japanese Brown cattle population by pedigree analysis. J Anim Breed Genet 2006; 123:172-9. https://doi.org/10.1111/ j.1439-0388.2006.00586.x

Jamieson IG, Allendorf FW. How does the 50/500 rule apply to MVPs?. Trends Ecol Evol 2012; 27:578-84. https://doi.org/10.1016/j. tree.2012.07.001

Lacy RC. Analysis of founder representation in pedigrees: founder equivalents and founder genome equivalents. Zoo Biol 1989; 8:111-23. https://doi.org/10.1002/zoo.1430080203

Lacy RC. Clarification of genetic terms and their use in the management of captive populations. Zoo Biol 1995; 14:565-78. https:// doi.org/10.1002/zoo.1430140609

MacCluer JW, Boyce AJ, Dyke B, Weitkamp LR, Pfenning DW, Parsons CJ. Inbreeding and pedigree structure in Standardbred horses. J Hered 1983; 74:394-9. https://doi.org/10.1093/ oxfordjournals.jhered.a109824

Maignel L, Boichard D, Verrier E. Genetic variability of French dairy breeds estimated from pedigree information. Interbull Bull 1996; 14:49-54. 
Martínez RA, García D, Gallego JL, Onofre G, PérezJ, CañónJ. Genetic variability in Colombian Creole cattle populations estimated by pedigree information. J Anim Sci 2008; 86:545-52. https://doi.org/10.2527/jas.2007-0175

Meuwissen THE, Luo Z. Computing inbreeding coefficients in large populations. Genet Sel Evol 1992; 24:305-13. doi:10.1186/1297-9686-24-4-305

Onogi A, Shirai K, Amano T. Investigation of genetic diversity and inbreeding in a Japanese native horse breed for suggestions on its conservation. Anim Sci J 2017; 88:1902-10. https://doi.org/10.1111/asj.12867

Pezzini T, Mariante AS, Martins E, Paiva S, Seixas L, Costas Jr JBG, Rolo J, McManus C. Population structure of Brazilian Crioula Lageana cattle (Bos taurus) breed. Rev Colomb Cienc Pecu 2018; 31:93-102.

Pinheiro M, Kjöllerström HJ, Oom MM. Genetic diversity and demographic structure of the endangered Sorraia horse breed assessed through pedigree analysis. Livest Sci 2013; 152:1-10. https://doi.org/10.1016/j.livsci.2012.11.017

Riley DG, Chase CCJr, Coleman SW, Olson TA. Evaluation of birth and weaning traits of Romosinuanocalvesaspurebredsand crosseswith Brahman and Angus. JAnim Sci2007; 85:289-98. https://doi.org/10.2527/jas.2006-416

Riley DG, Burke JM, Chase CCJr, Coleman SW. Heterosis and direct effects for Charolaissired calf weight and growth, cow weight and weight change, and rations of cow and calf weights and weight changes across warm season lactation in Romosinuano, Angus, and $\mathrm{F}_{1}$ cows in Arkansas. J Anim Sci 2016; 94:1-12. https://doi.org/10.2527/jas.2015-9484
Rosendo PA, Palacios JAL, Rosales MF, Torres HG, Ramírez VR, Becerril PCM. Genetic variability of Tropical Milking Criollo cattle of Mexicoestimated from genealogicalinformation. Rev Colomb Cienc Pecu 2018; 31:196-203. http://dx.doi.org/10.17533/udea.rccp.v31n3a04

Santana MLJr, Oliveira PS, Eler JP, Gutiérrez JP, Ferraz JBS. Pedigree analysis and inbreeding depression on growth traits in Brazilian Marchigiana and Bonsmara breeds. J Anim Sci 2012; 90:99-108. https://doi.org/10.2527/jas.2011-4079

Santana MLJr, Pereira RJ, Bignardi AB, El Faro L, Tonhati H, Albuquerque LG. History, structure, and genetic diversity of Brazilian Gir cattle. Livest Sci 2014; 163:26-33. https://doi.org/10.1016/j.livsci.2014.02.007

Santana MLJr, Pereira RJ, Bignardi AB, Ayres DR, Menezes GRO, Silva LOC, Leroy G, Machado CHC, Josahkian LA, Albuquerque LG. Structure and genetic diversity of Brazilian Zebu cattle breeds assessed by pedigree analysis. Livest Sci 2016; 187:6-15. https://doi.org/10.1016/j.livsci.2016.02.002

Scharf B, Carroll JA, Riley DG, Chase CCJr, Coleman SW, Keisler DH, Weaber RL, Spiers DE. Evaluation of physiological and blood serum differences in heat-tolerant (Romosinuano) and heat suceptible (Angus) Bos taurus cattle during controlled heat challenge. J Anim Sci 2010; 88:2321-36. https://doi.org/10.2527/jas.20092551

SAGARPA(SecretaríadeAgricultura, Ganadería, Desarrollo Rural, Pesca y Alimentación). Comunicado de Prensa BCS/226/2017. 2017; access date: 27/07/2017 http://sagarpa.gob.mx/ Delegaciones/bajacaliforniasur/boletines/2017/ junio/Documents/2017BS226.PDF 
Sheikhlou M, Abbasi MA. Genetic diversity of Iranian Lori-Bakhtiari sheep assessed by pedigree analysis. Small Ruminant Res 2016; 141:99-105. https://doi.org/10.1016/j. smallrumres.2016.07.009

Silva MHMA da, Malhado CHM, Costa JLJr, Cobuci JA, Costa CN, Carneiro PLS. Population genetic structure in the Holstein breed in Brazil. Trop Anim Health Prod 2016; 48:331-6. DOI: 10.1007/s11250-015-0956-7
Toro MA, Villanueva B, Fernández J. Genomics applied to management strategies in conservation programmes. Livest Sci 2014; 166:48-53. https://doi.org/10.1016/j.livsci.2014.04.020

Vassallo JM, Diaz C, Garcia-Medina JR. A note on the population structure of the Avileña breed of cattle in Spain. Livest Prod Sci 1986; 15:285-8. https://doi.org/10.1016/0301-6226(86)90035-7 